\title{
Histone H2A Type 1-H
}

National Cancer Institute

\section{Source}

National Cancer Institute. Histone H2A Type 1-H. NCI Thesaurus. Code C162912.

Histone H2A type 1-H (128 aa, $14 \mathrm{kDa}$ ) is encoded by the human H2AC12 gene. This protein is involved in nucleosome assembly. 